\title{
O ensino sobre a Lua e suas fases: uma proposta ensalo observacional para os Anos Iniciais do Ensino Fundamental
}

\author{
Paula Cristina da Silva Gonçalves \\ http://orcid.org/0000-0002-8646-2390 \\ Paulo Sergio Bretones \\ http://orcid.org/0000-0002-0623-8277
}

\section{Resumo:}

Este artigo expõe os resultados de uma pesquisa experimental sobre o ensino de Lua e suas fases, desenvolvida em uma turma de segundo ano do Ensino Fundamental, em uma escola pública. A investigação busca verificar o processo de aprendizagem tendo a observação do astro no céu pelos estudantes como base

Palavras-chave: Lua; Anos Iniciais; Observação do Céu. principal, utilizando o desenho como forma de registro e rodas de conversa, ambos acessíveis às crianças pequenas. Nosso objetivo é verificar quais questões e ideias emergem quando a observação está no cerne do processo e o que os estudantes demonstram compreender a partir dessa escolha metodológica, tendo em vista a formação dos conceitos científicos de Vigotski para crianças. A pesquisa evidencia o aprendizado dos discentes a respeito dos movimentos observáveis da Lua ao longo das noites, de sua mudança de aspecto, entre outras características.

\section{La enseñanza de la Luna y sus fases: una propuesta observacional para los primeros años de la Educación Primaria}

\section{Resumen:}

Este artículo expone los resultados de una investigación experimental sobre la enseñanza de la Luna y sus fases, desarrollada en una clase de segundo año de Primaria, en una escuela pública. La investigación buscó verificar el proceso de aprendizaje con la observación de la Luna en el cielo por parte de los estudiantes como base principal, utilizando el dibujo como forma de registro y círculos de conversación, ambos accesibles a los niños pequeños. Nuestro objetivo es verificar qué preguntas e ideas surgen cuando la observación está en el centro del proceso y qué los estudiantes demuestran comprender a partir de esta alternativa metodológica, considerando la formación de los conceptos científicos de Vygotski para los niños. La investigación demuestra el aprendizaje de los estudiantes sobre los movimientos
Palabras clave:

Luna; Primeros

años;

Observación

del cielo. 
observables de la Luna a lo largo de las noches, su cambio de aspecto, entre otras características.

\title{
Teaching about the Moon and its phases: an observational proposal for Elementary School
}

\begin{abstract}
:
This paper exposes the results of an experimental research about the teaching of the moon and its phases, developed with children in the second year of elementary, in a public school. The inquiry seeks to verify the learning process by observation of the Moon in sky by students as the main basis, using drawings as a form of registration and conversation circles, both accessible to young children. Our aim is to verify which questions and ideas emerge when observation is at the heart of the process and what students demonstrate to understand from this methodological choice, in view of the formation of scientific concepts of Vygotsky for children. The research highlights students' learning regarding the observable movements of the Moon throughout the nights, the change in aspect, as well as other characteristics.
\end{abstract}

Keywords:

Moon;

Elementary

School;

Sky

Observation.

\section{INTRODUÇÃO}

A Lua é um dos astros que desperta inspirações para diversas formas de expressão humana ao longo dos tempos, no cinema, nas artes plásticas, na poesia, nos contos, entre tantas outras, nos diferentes séculos e culturas, o que nos mostra o quanto é notável no céu e estimula a imaginação. Apesar de ser o corpo celeste mais próximo e estar entre os mais perceptíveis no céu, sua observação tem sido pouco considerada em pesquisas relacionadas a seu ensino. Há uma grande diversidade de recursos utilizados em estudos e processos de ensino sobre a Lua e suas fases, que envolvem materiais de baixo custo, como bola de isopor, softwares e simuladores, com uma forte tendência em abordar o astro e o fenômeno na perspectiva de sua ocorrência no sistema Sol-Terra-Lua, pouco incluindo e considerando a compreensão do satélite a partir de sua observação no ambiente imediato e cotidiano, que poderia ser especialmente aproveitado como ponto de partida ou, no mínimo, como parte integrante do ensino.

A Base Nacional Comum Curricular (Ministério da Educação, 2017) indica o início do trabalho pedagógico com a Lua como tema nos Anos Iniciais do Ensino Fundamental, no eixo Terra e Universo, de forma que o estudante tenha experiências de observação, perceba seu movimento e compreenda seu ciclo, bem como fenômenos decorrentes dele. O ciclo lunar pode ser acompanhado no período próximo a um mês e mesmo a observação por uma semana, de forma planejada, cria condições de percepção de seu movimento e de sua mudança de aparência.

Esta pesquisa tem como cerne a proposta de que os estudos sobre a Lua sejam iniciados por sua observação no céu para que apenas posteriormente se façam 
abstrações e modelizações. Para a Educação em Astronomia com crianças, essa é uma condição essencial na construção dos processos de compreensão. Todavia, há que se considerar a importância desse tipo de escolha metodológica, independentemente da idade dos estudantes e do nível de ensino, compreendendo que o conhecimento não deveria perder a relação com nosso cotidiano e o ambiente.

\section{O ENSINO DO TEMA LUA E A OBSERVAÇÃO DO CÉU}

Em investigação anterior (Gonçalves e Bretones, 2020), realizamos um levantamento panorâmico a respeito do ensino da Lua e de suas fases no Brasil. Analisamos 242 pesquisas, entre teses, dissertações, artigos e trabalhos apresentados em eventos desde a década de 1970 até 2015. Verificamos que, apesar da proximidade do astro e de certa facilidade em sua observação, esta pouco é incluída nos processos de ensino e aprendizagem da maior parte das pesquisas. Encontramos alguns trabalhos que propõem a dimensão da observação processual da Lua no céu no referencial topocêntrico: Lima (2006), Lago (2013), Jafelice (2015), Pellenz (2015) e Lago, Ortega e Mattos (2018).

É possível, portanto, concluir que nessas pesquisas investigadas sobre a Lua, a perspectiva observacional, vivencial, da escala humana, considerando o panorama do sujeito que vive no planeta Terra, pouco tem sido contemplada, em comparação ao total de trabalhos encontrados sobre o ensino do tema. Por outro lado, a dimensão espacial do satélite e os fenômenos que estão relacionados a ele no sistema Sol-Terra-Lua é o aspecto mais abordado.

É importante que, no ensino de Ciências para crianças, o ambiente imediato seja considerado de forma primordial. Nesse cenário, a Lua é o astro mais próximo e acessível, sem a necessidade de grandes tecnologias para os contatos mais elementares. Concordamos com Delizoicov e Slongo (2011) que destacam que, "antes mesmo de chegar à escola, a criança já realizou significativo percurso, explorando seu entorno. $\mathrm{O}$ ensino de Ciências nessa faixa escolar deve oportunizar à criança a exploração do mundo natural e social no qual está inserida" (p. 209).

Fracalanza, Amaral e Gouveia (1987) também afirmam a importância de olhar para o mundo natural, considerando essa etapa basilar para a crescente abstração:

\footnotetext{
Primeiro temos que propiciar à criança o conhecimento dos fatos a seu alcance, no tempo e no espaço. Em seguida estimular a comparação e a organização dos mesmos, de maneira a construir problemas autênticos que motivem e guiem seu raciocínio progressivamente para abstrações maiores. Aí estão incluídas a compreensão das relações mais complexas entre os diferentes aspectos físicos envolvidos com o fenômeno [...], bem como as suas verdadeiras causas (p. 69).
}

Tendo isso em vista, é interessante ponderar sobre o ensino desse tema, assim como dos demais em Astronomia e Ciências como um todo, no conjunto dessa complexidade que envolve a dimensão do observador, suas vivências e experiências de forma elementar, em especial para crianças, mas não somente para elas. As demais escalas dos fenômenos astronômicos, nessa perspectiva, começam a ser compreendidas na construção das relações entre o que vemos, as interações em nosso planeta, para 
progressivamente passar ao entendimento do que ocorre nas dimensões fora da Terra, que mobilizam saberes complexos e abstratos.

A maior parte da Astronomia básica pode ter seu ensino iniciado nessa lógica de priorizar o que percebemos enquanto seres deste planeta, o que afeta nosso cotidiano, como a sequência dos dias e das noites, a Lua e suas fases e as estações do ano, pois isso estimula um conhecimento contextualizado à realidade dos estudantes. Lanciano (1989) defende a importância da inclusão da perspectiva do observador nos processos educativos da Astronomia, compreendendo-o como parte significativa:

(. . .) trata-se de ser capaz e consciente de aceitar a possibilidade de manter os dois modelos diferentes, dois modelos de linguagem para se falar do mesmo: manter a visão ptolomaica cotidiana e sua relatividade com respeito a um sistema de mundo em que tudo se move e não existem centros locais relativos (p. 175, tradução nossa).

Kriner (2004) entende que aprender sobre fases da Lua não se restringe à descrição do fenômeno. Os estudantes precisam ter a possibilidade de compreender e relacionar suas características perceptivas com o modelo heliocêntrico. O modo como o ensino tem sido priorizado, bem como parte considerável das pesquisas desenvolvidas na área, parece manter o foco em apenas uma das escalas e dimensões dos fenômenos, sem favorecer a construção da compreensão gradativa da espacialidade dos eventos pelos estudantes e professores, o que é um desafio indicado por alguns autores (Bisch, 1998; Kriner, 2004; Leite, 2002, 2006).

Kriner (2004) afirma que o tema das fases da Lua é complexo de ensinar e difícil de aprender, em especial pelo alto grau de abstração necessário. Essa ideia se reforça, pois, apreensivamente, algumas pesquisas apontam que, mesmo após atravessar a escolarização básica ou após concluir uma licenciatura ou outra graduação e mesmo entre professores, ainda existe a predominância do entendimento confuso sobre as fases da Lua, que é um dos conteúdos contemplados no tema "Lua" ( Langhi \& Nardi, 2012; Leite, 2006; Peña \& Quílez, 2001; Puzzo, 2005; Plummer, 2008; Subramanian \& Padalkar, 2009). Com isso, é importante refletir em torno dos processos de ensino e aprendizagem sobre o tema ao longo da Educação Básica, o que também pode servir para ponderações a respeito de outras questões e conteúdos da área.

Além de privilegiar o acesso ao ambiente natural, esta proposta incentiva que a observação da Lua seja desenvolvida antes mesmo de uma abordagem teórica do assunto, sendo a etapa inicial. Essa ideia inspira-se nos trabalhos de Lanciano (1986, 1989), Lorenzoni (1988), Bisch (1998) e Jafelice (2002, 2010), que fazem discussões significativas a respeito da necessidade de as crianças terem contato com a natureza e perceberem-na no processo de ensino e aprendizagem sobre Astronomia, sem desconectar o que é abordado do mundo natural acessível. Para Lanciano $(1986,1989)$ e Lorenzoni (1988), os significados que as crianças pequenas estabelecem com aquilo que vivenciam e veem são fundamentais para o aprendizado.

Conforme Lanciano (1986), a dimensão do belo e do prazer são importantes na educação para os processos de conhecer, aprender e lembrar; e a experiência da observação do céu se relaciona também com essa perspectiva. A emoção e o espanto da ação de contemplar o céu podem ser alicerces para a construção do saber e gerar desejos por novos conhecimentos. Além disso, ainda segundo a autora, o tempo de espera para 
observar um fenômeno, como o nascer ou o pôr do Sol, pode ser um bom momento de preparação para que o corpo e a mente estejam no fenômeno.

Lorenzoni (1988) destaca a priorização escolar da memorização e do raciocínio e a escassa valorização de uma educação que sensibilize a percepção, que é a janela de nossa representação do mundo. Bisch (1998) expõe que

\begin{abstract}
uma Astronomia "de gabinete" pode ser justificada no caso de um astrônomo profissional, experiente, adulto, porém julgamos que uma Astronomia livresca, desembelezada, de sala de aula, é completamente fora de propósito no ensino fundamental, onde uma das atitudes mais importantes a exercitar nos alunos é a sua capacidade de observação da natureza, onde é essencial sensibilizá-los com relação à beleza e diversidade do universo, instigar sua curiosidade e imaginação (p. 125).
\end{abstract}

Nessa mesma perspectiva, Jafelice (2002, p. 12) afirma que se trata de um trabalho inicialmente não verbal e não racional restabelecer o contato com o céu e consigo: "É um trabalho essencial e primeiro, feito antes de se agregar qualquer conteúdo específico habitual ou instrumentos que mediarão suas observações". Com isso, os estudantes têm a oportunidade de pensar e construir ideias a respeito daquilo que observam. Jafelice (2010) propõe uma abordagem de Astronomia humanística em que se prioriza a vivência dos fenômenos antes de sistematizações:

do ponto de vista pedagógico, aspectos cognitivo-analítico-reflexivos envolvendo distribuição e leitura ou produção de textos com os alunos, análises, conceituações e etc. - só são contemplados, em geral, após os alunos terem vivenciado - isto é, feito e sentido no corpo, na prática - os fenômenos ou processos que nos interessa tratar naquela circunstância e tenham, em grande parte, descoberto por si mesmos a maioria das associações e informações que são possíveis de serem obtidas vivencialmente (pp. 216-217).

Essas perspectivas encontram consonância na teoria educacional de Vigotski (2009), que destaca a importância da interligação entre os conhecimentos espontâneos, desenvolvidos pelo sujeito em sua relação com o mundo, e a aprendizagem dos conceitos científicos, exercendo influência um sobre o outro:

\footnotetext{
No processo de ensino do sistema de conhecimentos, ensina-se à criança o que ela não tem diante dos olhos, o que vai além dos limites da sua experiência atual e da eventual experiência imediata. Pode-se dizer que a assimilação dos conceitos científicos se baseia igualmente nos conceitos elaborados no processo da própria existência da criança ... (. . .) de igual maneira, a assimilação do sistema de conhecimentos científicos também não é possível senão através dessa relação imediata com o mundo dos objetos, senão através de outros conceitos anteriormente elaborados. E essa formação de conceitos requer atos de pensamento inteiramente diversos, vinculados ao livre movimento no sistema de conceitos, à generalização de generalizações antes constituídas, a uma operação mais consciente e mais arbitrária com conceitos anteriores (pp. 268-269).
}

Assim, é fundamental a construção dessa experiência relacionada ao acessível para que os conhecimentos científicos não sejam só um ensino direto de conceitos, o que Vigotski (2009) destaca que se mostra pela prática e pela pesquisa "impossível e pedagogicamente estéril" (p. 247). O autor ainda afirma: 
O professor que se envereda por esse caminho costuma não conseguir se não uma assimilação vazia de palavras, um verbalismo puro e simples que estimula e imita a existência dos respectivos conceitos na criança, mas na prática, esconde o vazio. Em tais casos, a criança não assimila o conceito mas a palavra, capta mais de memória que de pensamento e sente-se impotente diante de qualquer tentativa de emprego consciente do conhecimento assimilado (p. 247).

Concordamos com os autores e entendemos que a construção do conhecimento abrange uma complexidade maior que os momentos pontuais de sala de aula, que envolve o desenvolvimento da criança, o mundo que a cerca e nossa cultura. Entendemos que é nessa base de relação entre o mundo acessível da criança que o saber sobre Astronomia pode se construir. Contudo, não se trata de algo sem direção. A observação proposta de forma sistematizada parte da consciência de que é a escola o espaço para a construção do saber sistematizado, do conhecimento científico. Esta pesquisa se constrói, então, a partir dessas reflexões sobre a relevância da observação, do acesso ao ambiente imediato da criança, sobre a importância de seus processos de pensamento e sobre as escalas que compõem os fenômenos relacionados à Lua.

\section{PROCEDIMENTOS METODOLÓGICOS}

Esta pesquisa qualitativa e de intervenção experimental foi desenvolvida com 22 crianças com idades de 7 e 8 anos, cursando o $2^{\circ}$ ano do Ensino Fundamental de uma escola pública municipal do interior do estado de São Paulo. Ao longo da pesquisa, houve movimentações nas matrículas, e o grupo foi reduzido para 17 estudantes. De acordo com Megid Neto (2011), a pesquisa de intervenção ocorre quando o pesquisador introduz um ou mais elementos novos ou variáveis em um processo, sendo a intervenção experimental um esforço para descrever e analisar determinado experimento com a introdução e a manipulação de uma ou mais variáveis.

Em pesquisa experimental de grupo único, compara-se o estágio inicial e posterior à intervenção, procurando evidências que indiquem relação de causa e efeito. Dessa maneira, são comparados os estudantes em suas situações iniciais, suas trajetórias durante a intervenção e as características do estágio final. Há uma busca por "presença de mudança", a partir de estruturas de verificação, de forma que não se produzem provas, mas uma indicação séria (Laville \& Dionne, 1999, p. 146). Neste artigo, apresentamos alguns dos dados encontrados, que podem ser verificados em sua totalidade em Simon (2016).

Os dados foram obtidos por meio de: entrevistas semiestruturadas antes e após as observações; desenhos feitos pelas crianças como registro; discussões em sala gravadas; anotações e acompanhamento pela pesquisadora em caderno de campo. A escolha pelas formas de registro e coletas de dados da pesquisa se deu especialmente em virtude de as crianças dessa faixa etária estarem em processo de alfabetização. Assim, seus registros por desenho e as suas falas foram basilares.

De acordo com Sarmento (2011), o desenho é uma forma de expressão, comunicação simbólica da criança, que precede a escrita, não representa apenas uma realidade exterior, "transporta, no gesto que o inscreve, formas infantis de apreensão do 
mundo" (p. 29). É, portanto, considerado um instrumento importante no processo metodológico.

Os desenhos das crianças e as discussões foram dados comparados em conjunto para verificar as expressões dos estudantes, por entender a fragilidade do desenho, uma vez que nem sempre uma ideia consegue ser expressa de forma nítida por meio dessa ferramenta. Além disso, as anotações do caderno de campo da pesquisadora também foram consultadas e comparadas.

As etapas da pesquisa com os estudantes estão descritas no Quadro 1:

Quadro 1. Etapas da pesquisa, tempo de desenvolvimento e descrição.

\begin{tabular}{|c|l|l|l|}
\hline N. & \multicolumn{1}{|c|}{ Etapa } & \multicolumn{1}{c|}{ Tempo } & \multicolumn{1}{c|}{ Descrição } \\
\hline 1 & $\begin{array}{l}\text { Levantamento inicial de } \\
\text { conhecimento dos } \\
\text { estudantes sobre o tema }\end{array}$ & $\begin{array}{l}4 \text { aulas distribuídas } \\
\text { em 1 semana }\end{array}$ & $\begin{array}{l}\text { Entrevistas semiestruturadas } \\
\text { filmadas }\end{array}$ \\
\hline 2 & $\begin{array}{l}\text { Primeira observação da } \\
\text { Lua na escola }\end{array}$ & 1 hora/noite & $\begin{array}{l}\text { Conhecer a Lua por meio do } \\
\text { telescópio }\end{array}$ \\
\hline 3 & $\begin{array}{l}\text { Observação do céu } \\
\text { diurno na escola }\end{array}$ & $\begin{array}{l}\text { 2 aulas em dois } \\
\text { dias diferentes }\end{array}$ & $\begin{array}{l}\text { Observar e registrar o céu } \\
\text { diurno }\end{array}$ \\
\hline 4 & $\begin{array}{l}\text { Observações individuais } \\
\text { da Lua e registro }\end{array}$ & $\begin{array}{l}6 \text { noites } \\
\text { distribuídas em 21 } \\
\text { dias }\end{array}$ & $\begin{array}{l}\text { Observar e registrar } \\
\text { individualmente as mudanças } \\
\text { da Lua ao longo das noites }\end{array}$ \\
\hline 5 & Análise dos registros & $\begin{array}{l}1 \text { aula após cada } \\
\text { observação }\end{array}$ & $\begin{array}{l}\text { Discussões em sala sobre os } \\
\text { registros dos alunos, } \\
\text { sistematizando as } \\
\text { aprendizagens }\end{array}$ \\
\hline 6 & Avaliação & $\begin{array}{l}6 \text { aulas distribuídas } \\
\text { em uma semana }\end{array}$ & $\begin{array}{l}\text { Sintetizar o que os alunos } \\
\text { aprenderam ao longo da } \\
\text { pesquisa }\end{array}$ \\
\hline
\end{tabular}

A Figura 1 expõe um esquema representativo da metodologia pedagógica desenvolvida ao longo de toda a proposta, incluindo todas as etapas:

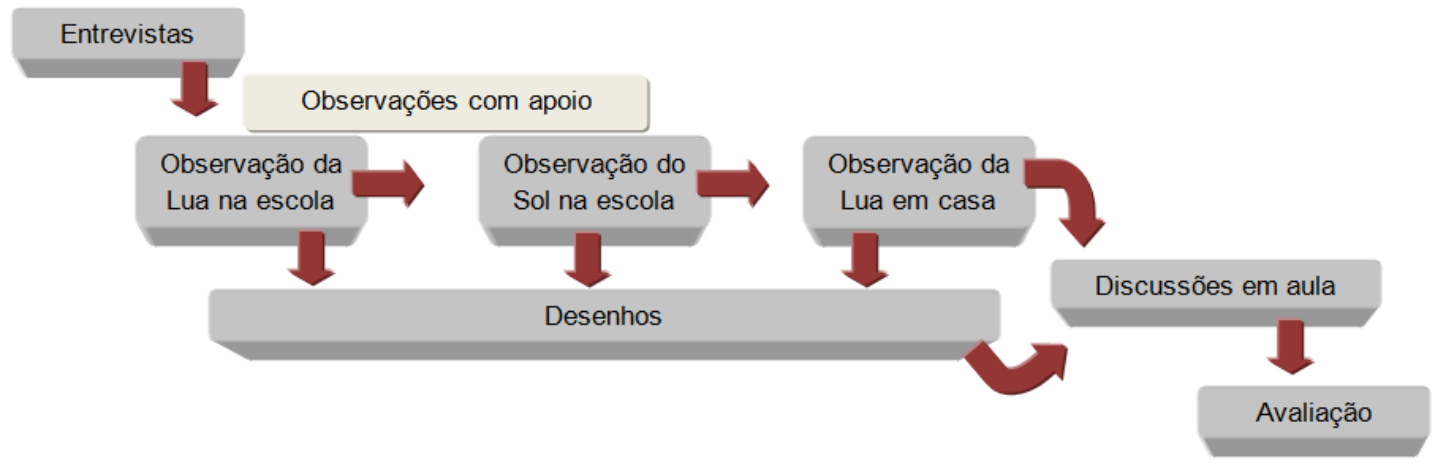

Fig. 1. Esquema representativo da metodologia pedagógica proposta.

Fonte: os autores

Iniciamos a proposta metodológica conversando com os estudantes sobre seus conhecimentos em relação à Lua e seguimos para as primeiras observações com apoio na escola. Essas observações tiveram caráter estruturante para que os estudantes 
desenvolvessem a proposta em casa, de forma autônoma, a etapa seguinte. Todas as observações eram registradas com um desenho, que incluía o registro do horizonte local, da data e da hora; no dia seguinte de cada observação, havia discussões em sala por meio da roda de conversa.

Além da preocupação com a aprendizagem dos estudantes, outras possibilidades emergem desse tipo de abordagem quando se parte da complexidade da natureza e do olhar infantil. É possível ir além dos conteúdos privilegiados convencionalmente no espaço escolar, quando o planejamento está aberto às questões que as crianças podem levantar.

\section{APRENDER ASTRONOMIA OBSERVANDO A LUA: APRESENTAÇÃO E DISCUSSÃO DOS DADOS}

Para o desenvolvimento inicial da proposta, realizamos entrevistas semiestruturadas com os alunos, com o intuito de verificar quais as ideias que apresentavam em relação à Lua e a suas fases. As perguntas iniciais foram: "Você costuma olhar o céu à noite?"; "O que você vê?"; "O que mais gosta de olhar no céu?". Se a Lua fosse citada, a próxima questão era: "O que você sabe sobre a Lua?". Essa maneira aberta deixava o estudante falar livremente e, a partir dessa pergunta, exploramos os seguintes tópicos: "Toda noite a Lua está no céu?"; “A gente pode ver ela de dia?"; "Ela sempre aparece igual?"; "Ela sempre está no mesmo lugar ou ela muda de lugar?".

Em relação à primeira pergunta, apenas duas crianças disseram que não costumavam olhar o céu à noite. Assim, seguiu-se a pergunta sobre o que o estudante mais gostava de olhar no céu, sendo mais citadas as estrelas, seguidas pela Lua. Quando as crianças não incluíam a Lua entre as coisas que viam no céu, ela era introduzida na entrevista.

Para as questões específicas sobre a Lua, a Tabela 1 mostra quais foram as respostas dos alunos:

Tabela 1: Respostas dos alunos às questões sobre a Lua.

\begin{tabular}{lccc}
\hline & Não sei & Não & Sim \\
A Lua muda de lugar? & 3 & 9 & 3 \\
A Lua aparece sempre igual? & 0 & 13 & 2 \\
A Lua pode ser vista de dia? & 0 & 6 & 9 \\
Toda noite a Lua está no céu? & 2 & 7 & 6 \\
\hline
\end{tabular}

Fonte: Elaborado pelos autores.

Como resultado, a maioria afirmou que a Lua muda de aparência (13), mas não muda de lugar (9). A turma estava dividida em relação à presença da Lua todas as noites no céu; e menos da metade dos alunos acreditava não ser possível vê-la de dia.

Em relação às duas primeiras perguntas, na pesquisa de Plummer (2009) com crianças de 6 a 8 anos, a autora verifica que os estudantes não acreditavam que a Lua tinha um movimento preciso no céu, apenas 3 alunos de 63 acreditavam que sim. Alguns alunos afirmaram que ela ficava parada mais ou menos no mesmo lugar à noite. 
A respeito da presença da Lua durante o dia e toda a noite no céu, Bisch (1998), em seu estudo, constata que existe um entendimento de oposição permanente e sincronizada entre a Lua e o Sol, o que significaria que, quando um dos astros está presente no céu, o outro não estaria. Apenas 2 estudantes, dos 18 que participaram de sua investigação, afirmaram que a Lua poderia ser vista de dia. Diferentemente, em Plummer (2009), a maioria dos educandos já percebia que a Lua poderia ser vista de dia.

Alguns discentes entrevistados por nós chegaram a citar as fases da Lua, para contar o que sabiam sobre o astro:

YA: Cheia, minguante, lua nova, crescente... Lua... só isso.

Pesq.: Você falou quatro nomes, são quatro luas?

YA: É uma só, só que a gente vê de quatro jeitos diferentes.

No trabalho de Bisch (1998), as crianças demonstraram entender que existia mais de uma Lua no céu, como se cada uma das fases fosse uma Lua. Nessa percepção, a Lua crescente seria uma Lua, a Cheia outra, assim com as demais fases principais, o que não reflete a compreensão de YA.

Algumas crianças citarem as fases mostra que já possuem alguns conhecimentos relacionados à Lua, que podem ter sido originados de diferentes formas, como a própria escolarização e as mídias, como a televisão. Citar essa informação não quer dizer necessariamente que o processo seja entendido pelo estudante e que este saiba o que ela significa. Vigotski $(2009$, p. 247) indica que se trata de um tipo de "verbalismo puro e simples" em que a criança conhece as palavras, porém não assimilou um conceito. Bisch (1998) chama de "chavões" termos memorizados de forma padrão, com origem científica, todavia ainda desconexos de uma rede de significações para o indivíduo que faz seu uso. O autor percebe isso em relação aos docentes que participaram de sua pesquisa, mas aqui podemos estender aos estudantes.

Algumas crianças também detalharam a explicação sobre a mudança de formato da Lua: "a escuridão embrulha a Lua", "as nuvens ficam na frente e escondem uma parte" e "muda de formato por causa do Sol". Baxter $(1989,1998)$ elenca pelo menos cinco tipos de explicações, além da correta, que as crianças apresentaram em seu trabalho para a mudança da aparência da forma da Lua: as nuvens cobrem parte da Lua; os planetas fazem sombra na Lua; a sombra é do Sol; a sombra da Terra se projeta na Lua.

O objetivo, com essas entrevistas, foi conhecer as ideias que as crianças tinham a respeito da Lua, de forma que as observações abrangessem questões que eles aparentavam não conhecer ainda. As ideias e as concepções que as crianças apresentam sobre a Lua e suas fases são bem abordadas nos trabalhos de Baxter (1989, 1998), Beraldo (1997), Bisch (1998), Stahly, Krockover e Shepardson, (1999), Leite (2002) Furtado (2005), Gonzaga (2009) e Plummer (2009). Vigotski (2009) destaca que os conceitos espontâneos são importantes, pois se inter-relacionam na construção dos conhecimentos científicos. Não se trata da substituição de um pelo outro. Segundo o autor, 
de informar e de empregar conceitos, mas que esse sistema e essa tomada de consciência já pressupõe a existência de conceitos infantis bastante ricos e maduros, sem os quais a criança não dispõe daquilo que deve tornar-se objeto da sua tomada de consciência e de sua sistematização (Vigotski, 2009, p. 293).

Assim, essas concepções que as crianças já possuem são fundamentais e se constituem em um terreno fértil para o conhecimento científico, com a intervenção do educador.

Na sequência, foi consultado se as crianças já haviam observado a Lua por meio de um telescópio, e verificamos que nenhuma delas teve essa experiência. Assim, marcamos a primeira observação do astro na escola, logo no início de uma lunação. $O$ interesse era a observação da Lua mesmo a olho nu, sem a necessidade do telescópio; entretanto, este foi utilizado com o intuito atrativo, buscando maior participação das famílias.

\section{Primeira observação da Lua na escola}

Foi combinado previamente com as crianças que cada uma faria o desenho de sua observação. A partir dos registros desenvolvidos nessa noite, foi possível perceber que, apesar de a proposta aparentar simplicidade por fazer uso do desenho, uma linguagem acessível a essa faixa etária, incluir o horizonte foi desafiador. Os alunos que não pudessem ir até à escola fariam a observação em suas casas.

Lorenzoni (1988), incentivando a observação da natureza, sugere que, se for realizada em relação à Lua, o desenho possível, em um ambiente com horizonte aberto, seria algo parecido com a Figura 2:

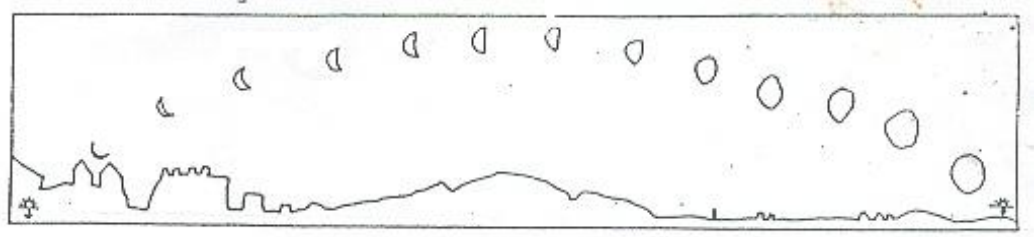

Fig. 2.

Lua no céu com relação ao horizonte para o hemisfério Sul.

Aspectos da Fonte: Adaptado de Lorenzoni (1988).

Compreendemos que, em função dos ambientes urbanos, essa amplitude de horizonte seria improvável, mas, apesar disso, seria interessante verificar as possibilidades da proposta.

Os desenhos feitos pelos estudantes mostraram grande sensibilidade na observação do céu desenvolvida na escola, no coletivo. Assim, corroboram o que Lorenzoni (1988) afirma sobre um processo educacional que sensibilize a percepção, que é a janela de nossa representação do mundo, assim como destacado por Jafelice (2010), proporcionando a vivência antes dos aspectos conceituais. 
Pode-se observar no desenho de NI (Figura 3) a Lua juntamente com as Três Marias (Cinturão de Órion) e os planetas Vênus e Júpiter. Na Figura 4, é exposta em destaque a área do céu registrada pelo estudante, desenvolvida no software Starry Night:

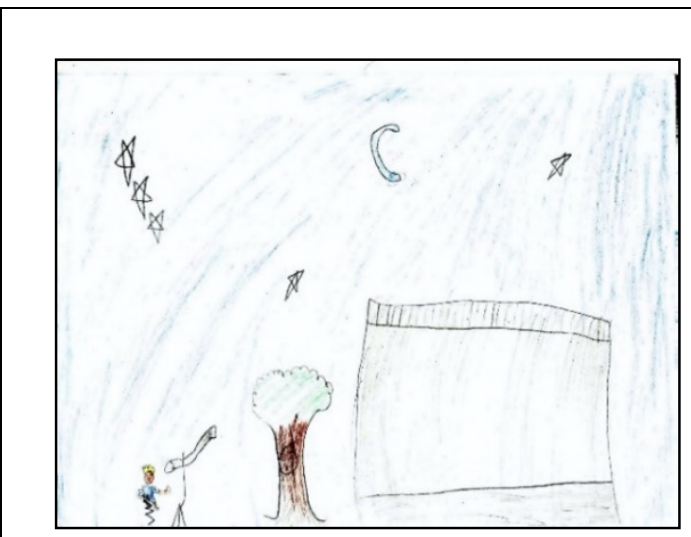

Fig. 3

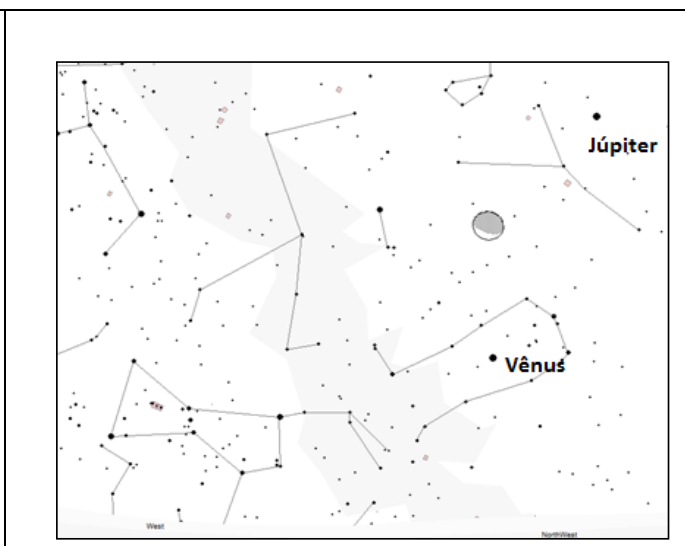

Fig. 4

Fig. 3 e 4. Registro da observação da Lua na escola de NI e do céu noturno (Starry Night) Fonte: Arquivo da pesquisa.

Como é possível notar, NI se inclui na paisagem com o horizonte. Não existe um problema em relação a isso; o objetivo era sensibilizar o olhar para o entorno, para a natureza e o horizonte.

Percebemos também, nessa primeira observação, a dificuldade de participação no período noturno, apesar do uso do telescópio, uma vez que, pela idade, os alunos dependem de seus pais para se locomoverem até a escola. Nessa noite, apenas 10 estudantes estavam presentes. Entendemos, a partir dessa situação, que não teríamos sequência de observação com muitas crianças, caso insistíssemos em realizá-la na escola. Então, repensamos o projeto, incluindo etapas não previstas, para que os estudantes realizassem as observações em suas casas, de forma autônoma.

O Quadro 2 apresenta a organização das observações, incluindo a reelaboração em relação ao local da observação:

Quadro 2. Dias de observações, locais e participação dos estudantes.

\begin{tabular}{|c|c|c|}
\hline Ordem/ Data & Observação & Local \\
\hline $1-22 / 05 / 2015$ & Primeira observação noturna da Lua & Na escola \\
\hline $2-12$ e $14 / 08 / 2015$ & Observações do céu diurno na escola & Na escola \\
\hline $3-16 / 08 / 2015$ & Segunda observação da Lua & Em casa \\
\hline $4-18 / 08 / 2015$ & Terceira observação da Lua & Em casa \\
\hline $5-22 / 08 / 2015$ & Quarta observação da Lua & Em casa \\
\hline $6-26 / 08 / 2015$ & Quinta observação da Lua & Em casa \\
\hline $7-29 / 08 / 2015$ & Sexta observação da Lua & Em casa \\
\hline $8-02 / 09 / 2015$ & Sétima observação da Lua & Em casa \\
\hline
\end{tabular}

\section{Observação do céu diurno na escola}


Para desenvolver ferramentas e condições para a realização da proposta, incluímos a observação do céu diurno na escola, com o horizonte local e o Sol, tendo o cuidado de não o observar diretamente. Em duas datas diferentes na mesma semana, sentamo-nos em uma área arborizada, e cada aluno fez seu registro com apoio e intervenção docente.

A atividade foi permeada de rodas de conversa em sala de aula. Os desenhos produzidos demonstraram compreensão da proposta, o que ofereceu a confiança para a continuidade. Nas Figuras 5 e 6, temos o desenho produzido por uma das alunas (JU) e uma foto do horizonte representado por ela:

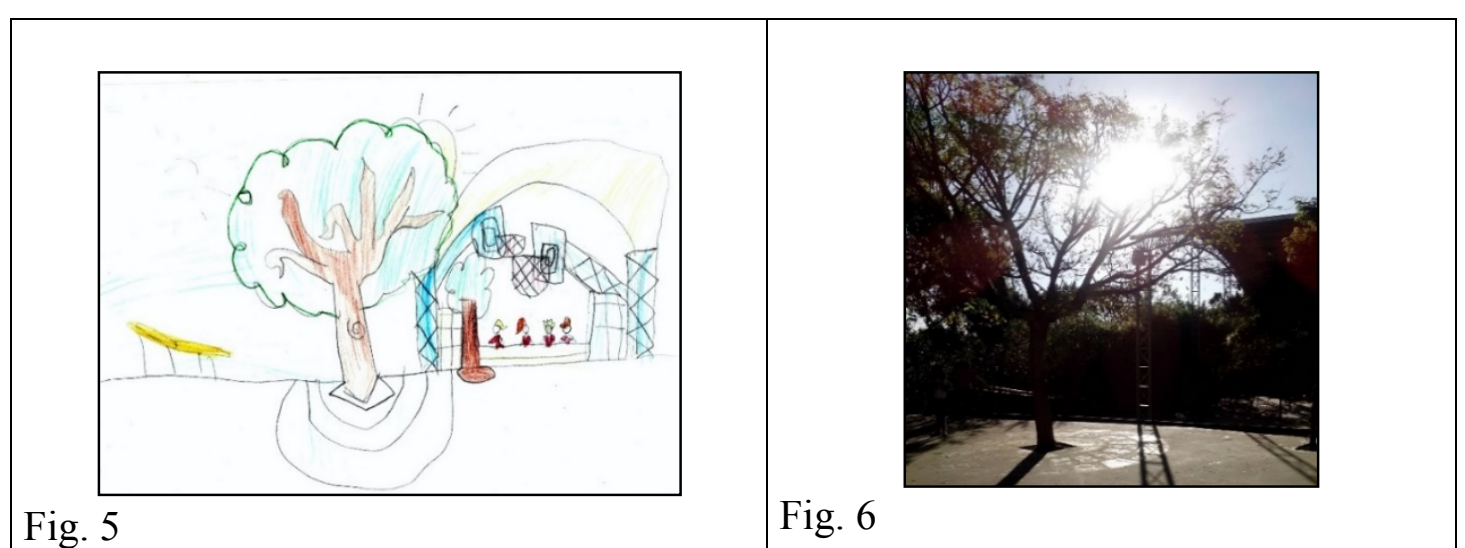

Fig. 5 e 6. Registro da observação diurna da aluna JU e imagem do horizonte de observação na escola Fonte: Arquivo da pesquisa.

Com o deslocamento do local da observação noturna da escola para a casa dos estudantes, a participação da turma foi massiva. Todos os alunos desenvolveram os desenhos, a sua maneira. Foi perceptível pelas conversas que alguns responsáveis auxiliaram as crianças nesse processo, acompanhando-as no quintal, na calçada ou na rua para que pudessem observar, mas, em alguns casos, foi evidenciado que não houve ajuda, e o estudante realizou a proposta sozinho. As famílias tinham conhecimento da atividade, pois ela havia sido apresentada e explicada em reunião.

Cada observação realizada foi compondo as páginas dos Cadernos de Observações individuais dos alunos, que eram montados progressivamente, conforme Figuras 7 e 8:

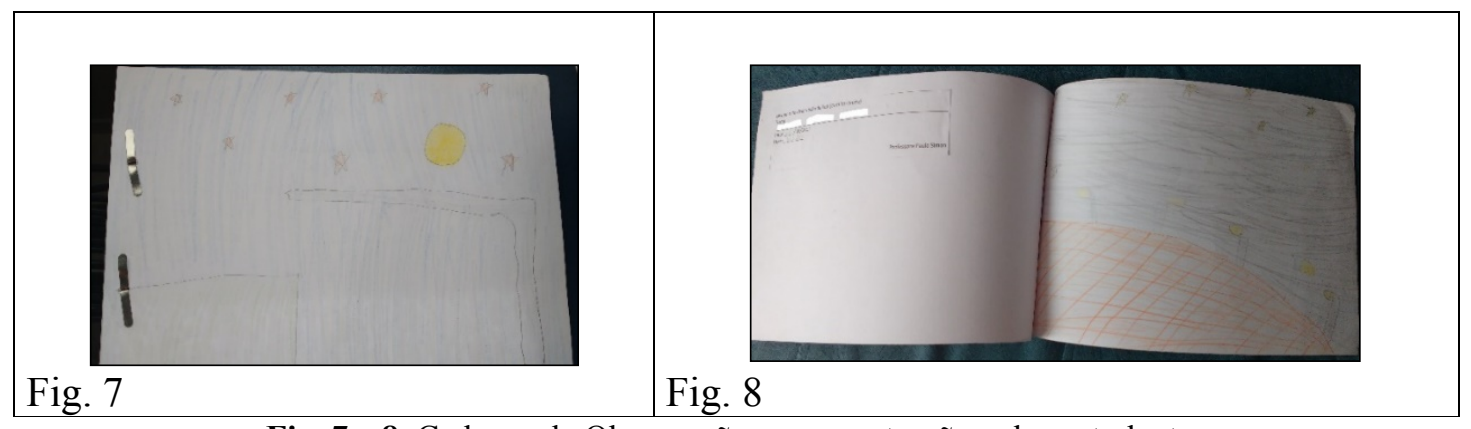

Fig. 7 e 8. Caderno de Observações em construção pelos estudantes Fonte: Arquivo da pesquisa. 


\section{Observações da Lua pelos estudantes em suas casas}

Após essas observações na escola com apoio e conversas, foi solicitado aos estudantes que, em algumas noites combinadas, observassem a Lua, procurando realizar a tarefa no mesmo horário e em lugares aproximados. Nesse mesmo período escolar, os alunos estavam aprendendo a ler as horas nos relógios analógicos e digitais, e não foi determinado um horário padrão para todos observarem, estimulando, assim, experiências mais individualizadas e a possibilidade dos estudantes. A observação era registrada em uma folha com espaço para tomar nota da data da observação e do horário.

Nas aulas subsequentes às noites de observação, foram realizadas rodas de conversa em que as crianças compartilhavam seus registros. Havia discussões em sala sobre o que elas haviam observado, ideias, questionamentos e elaboração de explicações. Os estudantes mostravam seus desenhos e apreciavam os dos colegas. Os desenhos das Figuras 9 e 10 mostram as primeiras observações e registros da aluna GA, realizados nos primeiros dias da Lua crescente, com um intervalo de dois dias entre elas:

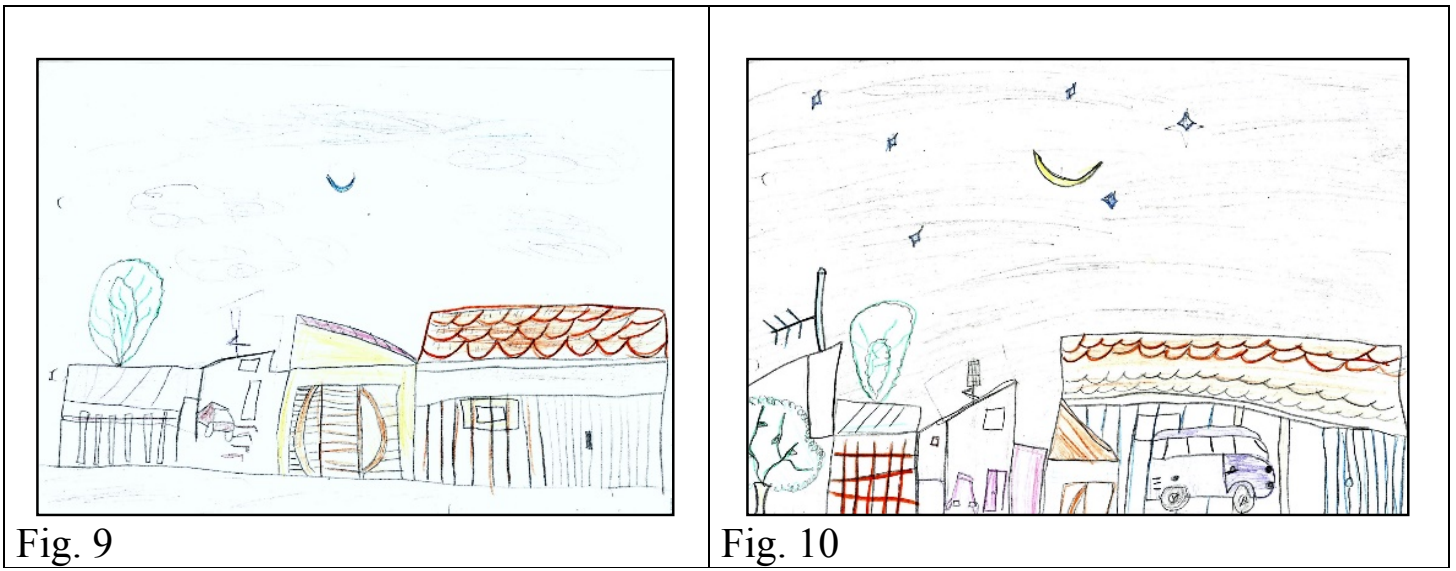

Fig. 9 e 10. Registros da Lua da aluna GA com dois dias de diferença.

Fonte: Arquivo da pesquisa.

Ao observar os dois desenhos da aluna GA, tomando como referência o telhado laranja e suas falas em sala de aula, podemos supor que ela percebeu que a Lua estava mais para a direita na segunda noite de observação, mantendo de forma parecida o horizonte em que realizou o registro. A conversa abaixo aconteceu em sala no dia subsequente à segunda observação e conta com a afirmação de GA sobre a mudança de posição:

YA: Ela estava assim igual a uma banana.

GA: Ontem a Lua estava mais ou menos igual, mas não estava no mesmo lugar.

NI: Na nossa casa estava mais para cima.

NI: No domingo, a lua "tava" parecendo uma banana murcha.

Pesq.: E ontem como ela estava aparecendo?

NI: Uma banana certa.

Podemos perceber pelas falas que as crianças notaram uma mudança de aparência e movimentação da Lua no céu já nas duas primeiras observações. 
Entre a segunda e a terceira observação em casa, perguntamos aos estudantes se eles acreditavam que, na próxima observação, a Lua teria uma aparência diferente. Curiosamente as crianças, em sua maioria, disseram acreditar que a Lua iria aparecer "mais fininha", como que retornando à forma da "banana".

Em conversa sobre a terceira observação em casa, que aconteceu 4 dias após a segunda, os alunos demonstraram notar que a Lua estava bastante diferente e que seu lugar no céu havia mudado, comparando os três desenhos já produzidos espalhados nas mesas:

GA: Dessa vez, ela estava muito diferente, ela estava um pouco mais gordinha, ela parecia uma melancia descascada e também um barco.

Pesq.: E ela estava no mesmo lugar?

Alunos em coro: Não.

Pesq.: E que lugar ela estava? Quando vocês foram observar, ela estava mais alta ou mais baixa no céu?

Os alunos afirmaram que a Lua estava mais alta no céu e um deles, AG, disse que precisou ir a um lugar diferente daquele em que fez as observações anteriores para poder enxergá-la: "Primeiro que a Lua estava aqui [apontando para seu desenho], depois subiu um pouco, depois ficou aqui atrás da casa, mais pra cima".

O desenho de KE (Figura 11) mostra a percepção da Lua "mais gordinha" citada pelos alunos e a limitação de seu horizonte de observação, a janela do apartamento onde morava:

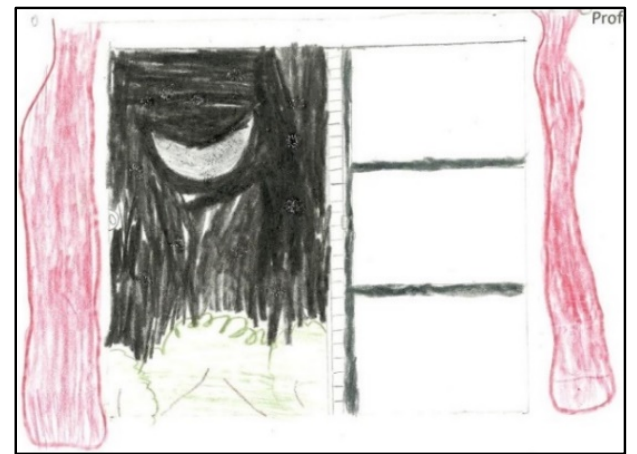

Fig. 11. Registro da Lua da aluna KE na terceira observação

Fonte: Arquivo da pesquisa.

Com quatro dias de diferença da observação anterior, os estudantes demonstraram perceber uma grande alteração na aparência da Lua e sua posição no céu, em relação às observações anteriores. Nessa roda de conversa, também foi perguntado a eles se acreditavam que a Lua era importante:

Pesq.: E a Lua é importante?

KE: Pra nós dormir, senão nós não vamos dormir.

HI: Todo dia, quando eu olho pra Lua, eu durmo.

AC: Se fosse de dia, a gente não podia dormir.

YN: A Lua é muito importante, porque quando, assim, se não tivesse a Lua, ficava só o Sol e não ficava a noite, ficava só de dia, e a gente não conseguiria dormir. 
Pesq.: Então, será que é a Lua quem traz a noite? Ou será que a gente teria noite mesmo se não existisse Lua?

GA: Não, é o Sol que ilumina uma parte, e a outra fica escura.

GS: Professora! É assim, professora, óh, aqui é a Terra e aqui é o Sol [faz com as mãos], né? O Sol só bate desse lado e aqui fica escuro... Daí... Sei lá, esqueci! KA: Aí, quando o Sol bate desse lado aqui, fica escuro.

GS: Isso que eu queria dizer...

Esse diálogo revela algumas questões interessantes da contribuição entre as crianças na elaboração de ideias e das primeiras manifestações sobre fenômenos fora do planeta, na perspectiva do sistema Sol-Terra. É possível que os estudantes não entendam necessariamente sua explanação de maneira científica, provavelmente viram algo sobre isso em desenhos ou outras fontes, mas evidenciaram a ideia no decorrer da conversa. As falas indicam o que Vigotski (2009) afirma sobre a sistematização e a tomada de consciência da criança em relação aos conceitos se deslocarem da própria criança em sua maneira de informar e de empregá-los, a partir de conceitos elementares desenvolvidos. Ou seja, há um movimento de inter-relações, e não a substituição de uma ideia por outra.

Nesse trecho da roda de conversa, é possível notar que se inicia uma discussão sobre o dia e a noite. As ideias apresentadas pelas crianças sobre uma oposição entre o Sol e a Lua, como se o primeiro fosse o responsável pelo dia e a segunda pela noite, centrados em uma espécie de revezamento no céu, já havia aparecido na entrevista inicial. É interessante notar que foi um assunto que teve colaboração dos próprios colegas para obter uma explicação mais correta, mesmo que não necessariamente completa. De acordo com Vigotski (2009),

em colaboração a criança sempre pode fazer mais do que sozinha. (. . .) A possibilidade maior ou menor de que a criança passe do que sabe fazer sozinha para o que sabe fazer em colaboração é o sintoma mais sensível que caracteriza a dinâmica do desenvolvimento e o êxito da criança (p. 329).

Podemos notar isso pela explicação do fenômeno de forma correta, iniciada por uma criança e complementada por outras.

Oliveira (2010) destaca que a ênfase dada à dimensão sócio-histórica na teoria de Vigotski se relaciona ao pensamento de que a aprendizagem é um processo que inclui a relação entre indivíduos - nesta proposta, não apenas entre alunos e professora na sala, mas entre os pares:

\footnotetext{
$\mathrm{Na}$ construção dos processos psicológicos tipicamente humanos, é necessário postular relações interpessoais: a interação do sujeito com o mundo se dá pela mediação feita por outros sujeitos. Do mesmo modo que o desenvolvimento não é um processo de maturação, a aprendizagem não é fruto apenas de uma interação entre o indivíduo e o meio. A relação que se dá na aprendizagem é essencial para a própria definição desse processo, que nunca ocorre no indivíduo isolado (p. 56).
}

Assim, as rodas de conversa, as ideias das crianças, as perguntas que a professora pesquisadora faz, são fundamentais para a aprendizagem.

Ainda respondendo à questão sobre a importância da Lua, a aluna IA, que morava em ambiente rural, disse: " $E$ importante a Lua, porque, às vezes, alguém tem medo de 
ficar no escuro". Isso denota uma relação diferente da que estabelecemos com o astro nos ambientes urbanos, onde, muitas vezes, nem é possível perceber a iluminação causada pela luz do luar em função da interferência da luminosidade artificial das cidades.

Na quarta observação em casa, a Lua estava há poucos dias da fase cheia. Com isso, os desenhos dos estudantes aparentavam uma Lua cheia. Nas conversas da sala, algumas crianças acreditavam que era a fase da Lua cheia de fato. Questionados sobre o formato, se ela estava de fato "bem cheia" ou quase, a maioria das crianças afirmou que era quase; e assim seguiu-se a conversa:

RI: Ooô, prô, sábado é dia de Lua cheia.

Pesq.: Como você sabe?

RI: $E u$ vi $C H E-I-A$.

Pesq.: Aonde você viu?

RI: Embaixo do 29, tá ali escrito cheia [apontando para o dia 29 no calendário].

Pesq.: E qual será aquela que vocês viram ontem?

NI: Lua nova...

GA e JU: Cheia.

NI: Minguante ... Eu acho que é minguante, porque não estava muito cheia...

GA: Nova, eu acho...

NI: Deixa eu ver, ontem foi dia 27? [Indo para o calendário].

GA: Aaah! É crescente.

NI: Cres-cen-te.

A percepção de que o calendário da sala que utilizamos ao longo do ano para organizar nossas atividades registrava a fase da Lua foi uma descoberta das crianças, sem a indicação da docente. Assim, elas já se anteciparam sabendo que, na próxima observação, veríamos a Lua cheia de fato. Nesse momento, a aluna GA afirmou que " $a$ [Lua] cheia fica muito amarela", o que pode expressar que a estudante relembrou uma observação anterior em alguma situação da vida e sua percepção.

Após a quarta observação, alguns alunos começaram a falar sobre ter visto algo ou reparado em algo sobre a Lua fora dos dias combinados para a observação com registro e fora dos momentos de roda de conversa sobre o tema, de forma espontânea. Em uma das aulas, um aluno disse que havia visto a Lua no céu durante o dia, o que levou a uma manifestação de parte da sala e desenvolveu uma conversa em torno dessa questão. Outro estudante reparou na imagem da Lua exibida na TV durante um jogo de futebol. Essas falas podem ser a expressão de um interesse pelo astro que extrapola o espaço e o tempo das abordagens escolares planejadas, corroborando o exposto por Lanciano (1986), que indica que as atividades de observação podem despertar desejos por novos conhecimentos.

A quinta observação em casa foi marcada para o dia que seria Lua cheia. Segue parte da conversa que aconteceu em sala após o final de semana da observação:

Pesq.: Como a Lua estava no sábado?

Crianças: Estava cheia.

GA: E ela tava brilhando, professora, bem forte!

Pesq.: E você falou outro dia que, quando a Lua estava cheia, ela ficava amarela. Ela estava amarela? 
GA: Não..., mas algumas vezes fica...

Notar essa mudança em relação à coloração da Lua é algo interessante, sensível e relacionado com nossa atmosfera, especialmente quando ela está próxima ao horizonte. Esse tipo de observação potencializa perguntas sobre o porquê de isso acontecer. Mesmo não se estendendo nessa questão, a aluna retomar a lembrança da coloração e observar a variação é bastante relevante no sentido de ampliação do que se sabe sobre $\mathrm{o}$ astro nessa perspectiva vivencial. $\mathrm{O}$ desenho das observações dos alunos AG e KE estão nas Figuras 12 e 13:

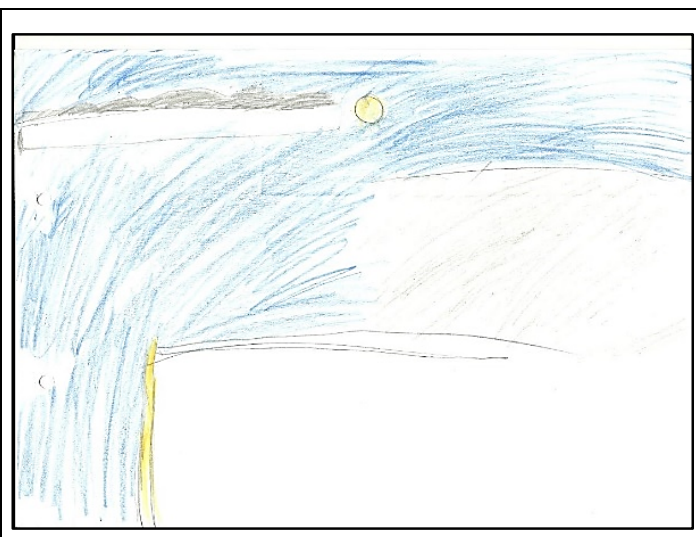

Fig. 12

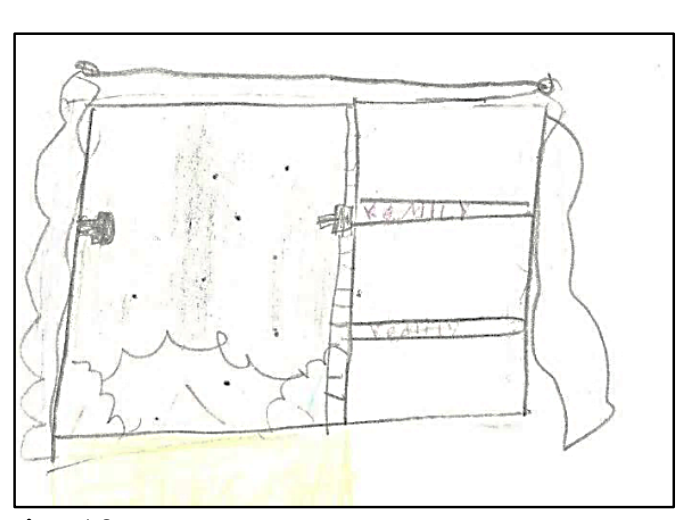

Fig. 13

Fig. 12 e 13. Registros da Lua do aluno AG (esquerda) e da aluna KE (direita) da quarta observação Fonte: Arquivo da pesquisa.

Podemos perceber a Lua de AG bem próxima à imagem de uma Lua cheia e a situação de observação da aluna $\mathrm{KE}$, que, nesse período, já não conseguia mais observar a Lua de sua janela nos mesmos horários e acompanhou o registro da Lua dos amigos que tiveram acesso a horizontes mais amplos.

A última observação foi marcada para uma data em que os estudantes não poderiam ver a Lua nos horários em que costumavam fazer suas observações. Com isso, o espanto e as elaborações das ideias sobre esse fato renderam longas conversas e ideias sobre o porquê de não terem encontrado a Lua no céu. As proposições apresentadas pelas crianças foram variadas, algumas cogitaram que ela poderia estar do outro lado da casa, atrás de uma nuvem, até que uma aluna levantou a ideia de que ela poderia estar "mais para baixo":

Pesq.: Como que você viu a Lua ontem?

AC: Eu não achei a Lua...

Pesq.: E você, Ga?

GA: Não vi a Lua, porque eu acho que eu vi muito tarde.

Pesq.: Por que será que muita gente não viu a Lua?

NI: Eu acho que é as nuvens.

GA: Eu acho que, na frente da minha casa, não tava mostrando ela, mas eu acho que atrás tava...

[As crianças YA e NI afirmaram, a partir da fala de GA, que olharam para todos os lados e mesmo assim não encontraram a Lua. Assim, a aluna GA concluiu:]

Pesq.: Onde será então que ela [Lua] tava?

GA: Eu acho que a Lua tava um pouco mais baixa.

Pesq.: Como assim mais baixa? 
GA: Ela tava um pouco mais pra baixo.

Entendemos que a fala de GA faz referência ao horizonte, quando levantou a possibilidade de que as crianças não haviam encontrado a Lua, pois esta estaria "mais baixa". De acordo com as afirmações dos estudantes, podemos observar certa compreensão sobre o movimento aparente da Lua, uma vez que alguns afirmaram que fizeram a observação muito tarde, que a Lua deveria estar mais para baixo, que ela poderia estar em outra parte do céu, não sendo possível vê-la de seu horizonte local.

Os desenhos dos alunos AN e HI ilustram essa situação:

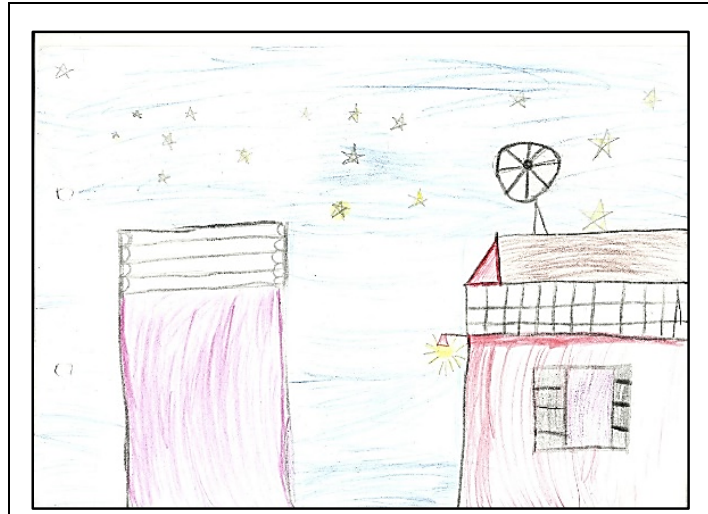

Fig. 14

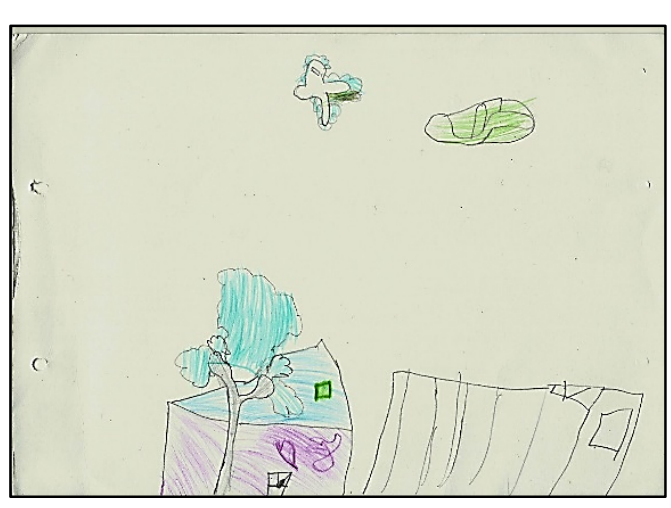

Fig. 15

Fig. 14 e 15. Registros da aluna AN (esquerda) e do aluno HI (direita) da última observação. Fonte: Arquivo da pesquisa.

As figuras mostram desenhos sem a Lua, como de fato seria a observação nos horários em que os estudantes estavam habituados. No desenho de HI, segundo suas falas, temos no céu o registro de um avião que passava enquanto o aluno fazia a observação noturna, mas ilustrado de forma diurna e próxima (figura central do céu) e de uma nave espacial (à direita).

Além dessa percepção, a questão estética surgiu na fala da aluna IA, que expôs os sentimentos que a Lua desperta nela: "A Lua é bem bonita também, não dá pra parar de olhar pra ela; quando eu 'tô' tipo tristinha, eu fico olhando pra ela, coloco um pano lá no chão de casa e fico olhando pra ela...".

De acordo com Seniciato e Cavassan (2009), as aprendizagens em ambientes naturais podem contribuir para uma experiência estética diferente das relações que costumamos manter diariamente, mediada pela funcionalidade. Isso se relaciona também com a discussão sobre a coloração da Lua que a aluna GA apresentou na quarta observação. Dessa maneira,

\footnotetext{
no caso dos ambientes naturais, essa reflexão implica, em última análise, a maneira como o processo educativo contribuirá para a conduta dos indivíduos em relação aos ambientes naturais. Se a experiência estética, caracterizada por essa aproximação entre o homem e o objeto natural, faz o homem refletir sobre si mesmo, o faz refletir, simultaneamente, sobre o objeto natural (Seniciato \& Cavassan, 2009, p. 397).
}

A passagem apressada pelos conteúdos costuma não possibilitar a criação dos momentos para o sentir, para o estético, o que acaba por deixar essa dimensão afastada do espaço escolar. 
Como síntese, o Quadro 3 apresenta o número das observações e as percepções e os conhecimentos demonstrados pelos estudantes por meio dos desenhos e das falas nas rodas de conversa:

Quadro 3. Número das observações e percepções e conhecimentos demonstrados

\begin{tabular}{|c|l|}
\hline Ordem & Percepções e Conhecimentos demonstrados \\
\hline 1 & $\begin{array}{l}\text { Identificar e registrar a posição da Lua no céu } \\
\text { Identificar e registrar planetas no céu: Vênus e Júpiter } \\
\text { Identificar a constelação de Órion } \\
\text { Conhecer o telescópio } \\
\text { Observar as crateras lunares }\end{array}$ \\
\hline 2 & Observar e registrar o horizonte com apoio na escola \\
\hline 3 & Registrar a Lua de forma autônoma \\
\hline 4 & $\begin{array}{l}\text { Perceber a mudança de posição da Lua, considerando o horizonte } \\
\text { Perceber pequena mudança em sua aparência }\end{array}$ \\
\hline 5 & $\begin{array}{l}\text { Constatar a mudança de aspecto e posição da Lua } \\
\text { Observar a Lua em outros horários, por iniciativa dos alunos }\end{array}$ \\
\hline 6 & $\begin{array}{l}\text { Perceber a mudança contínua no formato visível da Lua } \\
\text { Averiguar a modificação da posição da Lua no céu } \\
\text { Enxergar a mudança de direção da visualização e fazer o registro da } \\
\text { Lua } \\
\text { Construir a relação com outras esferas de nossa vida: o calendário }\end{array}$ \\
\hline 7 & $\begin{array}{l}\text { Ver a intensidade do brilho } \\
\text { Visualizar alterações significativas em sua cor aparente }\end{array}$ \\
\hline 8 & $\begin{array}{l}\text { Elaborar explicações para não terem observado a Lua em certas } \\
\text { noites }\end{array}$ \\
\hline
\end{tabular}

\section{Entrevistas Finais}

Após a última observação realizada, de forma a somar com os dados processuais, realizamos uma nova entrevista com as crianças, com a intenção de verificar o que elas acreditavam ter aprendido com as atividades. Essas entrevistas foram importantes para produzir sínteses básicas da turma, uma vez que nem todas as crianças participaram de maneira igual nas rodas de conversa, bem como os desenhos nem sempre atenderam a proposta de forma estruturada pela faixa etária dos estudantes.

As perguntas iniciais abertas foram: "Você lembra dos estudos que fizemos sobre a Lua?"; "O que você acha que aprendeu com aquilo que fizemos?". Com a entrevista com questões abertas, os alunos se manifestaram sobre diferentes aspectos, e conduzimos a conversa para saber se eles perceberam as mudanças de aparência ao longo das noites e a alteração de posição perceptível, quando os estudantes não incluíam esses temas em sua fala.

Sobre a mudança de aparência da Lua, todas as crianças confirmaram que a Lua muda sua forma aparente, sendo que algumas complementaram explicando que essa situação ocorreu por conta do Sol, outras disseram que era por conta da Terra. Em relação à mudança de posição no céu, todos os educandos indicaram que a Lua muda de lugar, com exceção de uma criança que não participou da última entrevista. Outros discentes complementaram suas explicações com a informação de que a Terra também 
está se movimentando. Acreditamos que esse tipo de afirmação reflita as primeiras sistematizações do sistema Sol-Terra-Lua em sua relação espacial (Quadro 4):

Quadro 4. Percepções dos alunos sobre a mudança da Lua no céu

\begin{tabular}{|c|c|c|c|c|c|}
\hline Estudante & $\begin{array}{c}\text { Entrevista } \\
\text { inicial }\end{array}$ & $\begin{array}{l}\text { Entrevista } \\
\text { final }\end{array}$ & Estudante & $\begin{array}{c}\text { Entrevista } \\
\text { inicial }\end{array}$ & $\begin{array}{c}\text { Entrevista } \\
\text { final }\end{array}$ \\
\hline $\mathrm{AG}$ & $\mathrm{A}$ & B & KA & B & $\mathrm{B}$ \\
\hline $\mathrm{AC}$ & $\mathrm{A}$ & $\mathrm{C}$ & $\mathrm{KE}$ & A & $\mathrm{C}$ \\
\hline NA & $\mathrm{A}$ & B & MA & A & B \\
\hline $\mathrm{BE}$ & $\mathrm{A}$ & $\mathrm{B}$ & NI & $\mathrm{B}$ & $\mathrm{C}$ \\
\hline $\mathrm{CA}$ & $\mathrm{D}$ & $\mathrm{B}$ & RI & $\mathrm{D}$ & $\mathrm{C}$ \\
\hline GA & $\mathrm{A}$ & $\mathrm{C}$ & YA & $\mathrm{D}$ & $\mathrm{B}$ \\
\hline GS & B & $\mathrm{C}$ & IA & D & $\mathrm{C}$ \\
\hline $\mathrm{HI}$ & A & B & $\mathrm{HY}$ & $\mathrm{D}$ & $\mathrm{D}$ \\
\hline $\mathrm{JU}$ & $\mathrm{A}$ & $\mathrm{B}$ & & & \\
\hline
\end{tabular}

Legenda: A - Não muda de lugar; B - Muda de lugar; C - Muda de lugar, e a Terra se movimenta; D Não responderam.

Com a variação de estudantes na sala ao longo do ano, realizamos o processo completo apenas com 17 alunos.

Se a Lua for observada em horário aproximado ao longo do tempo proposto, teríamos a constituição de um desenho próximo ao que se apresenta na Figura 2. Considerando que as crianças não tinham um horizonte aberto conforme o da figura para observação e que os desenhos não puderam expressar ao longo de toda a proposta o movimento de maneira clara, realizamos uma pergunta-síntese para verificar a percepção em relação ao movimento observável. Apresentamos dois desenhos (Figuras 16 e 17) com um horizonte qualquer, mas explicando que as observações foram registradas na mesma folha, e indagamos qual desenho se aproximava mais do que o estudante havia observado nesses estudos sobre a Lua:

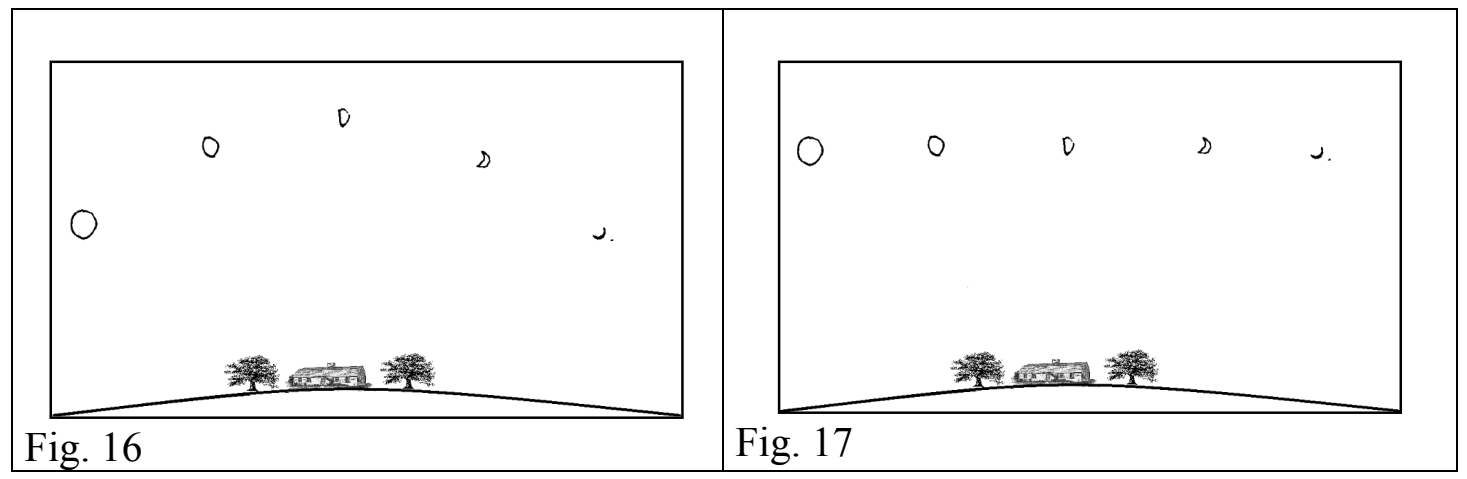

Fig. 16 e 17. Movimento aparente da Lua: Opção 1 e Opção 2

Fonte: Adaptado de Lorenzoni (1988).

Catorze estudantes afirmaram que a opção em que a Lua mudava de altura era a mais próxima do que eles haviam observado (Figura 16), dois deles responderam demonstrando certa insegurança; enquanto algumas das crianças explicaram espontaneamente que notaram ela "mais alta" e "mais baixa" em alguns dias. Apenas dois alunos escolheram a opção 2 (Figura 17); e um educando não participou da entrevista. Dessa forma, $82 \%$ das crianças demonstraram compreender o movimento 
observado ao longo das noites, apenas $12 \%$ acreditavam que ela não variava de altura ao longo das noites observadas, e $6 \%$ não responderam a essa pergunta.

Com a comparação das entrevistas, considerando todo o percurso da proposta, podemos afirmar que, com exceção do aluno que não respondeu às entrevistas, todos os demais demonstraram desenvolvimento em relação aos conceitos sobre a Lua, sua mudança de aparência e seus movimentos. Isso corrobora as afirmações de Vigotski (2009) sobre o desenvolvimento dos conceitos científico nas crianças:

O desenvolvimento dos conceitos científicos começa no campo da consciência e da arbitrariedade e continua adiante, crescendo de cima para baixo no campo da experiência pessoal e da concretude. O desenvolvimento dos conceitos científicos começa no campo da concretude e do empirismo e se movimenta no sentido das propriedades superiores dos conceitos: da consciência e da arbitrariedade (p. 350).

Diferentemente do ensino direto de conceitos, apontado por Vigotski (2009) como vazio e estéril, a proposta partindo da observação, dos desenhos e dos diálogos com as crianças buscou estimular as experiências acessíveis e importantes diante dos olhos dos estudantes, de forma mediada e intencional, sem a qual a assimilação do sistema de conhecimentos científicos não é possível.

\section{CONSIDERAÇÕES FINAIS}

Tendo em vista os objetivos da proposta, verificamos que, quando priorizamos a observação da Lua de forma sistematizada e acompanhada das intervenções docente e das rodas de conversa entre os estudantes, estes demonstraram percepção de uma série de questões sobre a Lua e suas fases, de forma assertiva. A maior parte dos estudantes revelou compreender os movimentos observáveis da Lua no céu, bem como sua mudança de aparência ao longo das noites de observação, em parte de uma lunação. Algumas crianças estabeleceram relações entre as observações e informações sobre o fenômeno espacial, obtidas antes, possivelmente em sua escolarização, na mídia etc.

Assim como as diferentes intervenções pedagógicas, essa proposta não alcançou todos os alunos. Alguns deixaram de realizar as atividades em alguns momentos por diversas razões, mas os dados mostram que o alcance foi significativo.

Partimos de uma proposta de Astronomia vivencial e buscamos sensibilizar os estudantes para a observação do céu e para a experiência. Analisando a trajetória do processo pedagógico e dos resultados, podemos afirmar que, apesar das dificuldades, houve desenvolvimento de conceitos científicos, não no sentido completo de nosso conhecimento sistematizado em sociedade sobre a Lua, mas adequado para o nível escolar e para a faixa etária dos estudantes.

Esse tipo de metodologia indica o potencial dos estudantes para concluir questões importantes da natureza pela experiência, de forma diversa do compartilhamento de informações e de seu acúmulo apressado. Certamente, existem outros conteúdos em Astronomia menos acessíveis à experiência, todavia a parte mais básica dessa área pode incluir a observação intencional como princípio para a aprendizagem, sem a ansiedade e a demanda de esgotar e organizar o conhecimento de forma completa e acabada sobre 
determinado assunto num único ano escolar. A relevância desse tipo de abordagem centraliza-se nos processos, nos caminhos trilhados e não apenas nos resultados que eles alcançam.

Esse desenvolvimento de conceitos científicos, pela perspectiva de Vigotski, continua a dialogar com os espontâneos da criança. Assim, com o tempo, a criança desenvolverá outros conceitos que dialoguem e se desenvolvam com estes da pesquisa, ao longo de sua escolaridade, quando esse tema voltar a ser abordado de forma mais complexa. É muito possível que, assim como ocorreu nesta experiência, os estudantes sejam capazes de se organizar e desenvolver a observação e o estudo de outros astros, com auxílio.

Novas pesquisas que partam da observação podem contemplar a compreensão do caminho que a Lua faz no céu, as demais fases, assim como avançar para o fenômeno espacial, especialmente com crianças mais velhas. Durante a escolarização básica, se houver mais práticas elaboradas nessa perspectiva, complexificando as discussões, pode-se idealizar que os estudantes progressivamente elaborem ideias e conclusões relacionadas, por exemplo, ao sistema Sol-Terra-Lua, refletindo sobre a relação espacial do fenômeno. No entanto, para o nível escolar com o qual trabalhamos, ponderações e estudos relacionados à perspectiva do sujeito, topocêntrica, são imprescindíveis.

\section{REFERÊNCIAS}

Baxter, J. (1989). Children's understanding of familiar astronomical events, International Journal of Science Education, 11, 502-513. https://doi.org/10.1080/0950069890110503.

Baxter, J. (1998). The influences of the National Curriculum on children's misconceptions about Astronomy and the use of these misconceptions in the development of interactive teaching materials. In: L. Gouguenheim, D. McNally \& J. R. Percy (Orgs.), New trends in Astronomy teaching (pp. 139-146). Cambridge: University Press.

Beraldo, T. M. L. (1997). O ensino de conceitos relacionados com a Terra no espaço,nas séries iniciais do Ensino Fundamental: elementos para reflexão em torno da formação docente. (Dissertação de Mestrado, Instituto de Educação, Universidade Federal de Mato Grosso, Mato Grosso).

Bisch, S. M. (1998). Astronomia no Ensino Fundamental: Natureza e Conteúdo do Conhecimento de Estudantes e Professores. (Tese de Doutorado, Faculdade de Educação, Universidade de São Paulo, São Paulo).

Delizoicov, N. C., \& Slongo, I. I. P. (2011). O ensino de Ciências nos anos iniciais do Ensino Fundamental: elementos para uma reflexão sobre a prática pedagógica. SérieEstudos: Periódico do programa de Pós-graduação em Educação da UCDB, 32, p. $205-$ 221.

Fracalanza, H., Amaral, I. A., \& Gouvea, M. S. F. (1987). O ensino de Ciências no Primeiro Grau. São Paulo: Atual. 
Furtado, L. M. (2005). O mundo é o lugar: um estudo das representações dos professores sobre os fenômenos astronômicos. (Dissertação de Mestrado, Faculdade de Educação, Universidade de São Paulo, São Paulo).

Gonçalves, P. C. da S. e Bretones, P. S. (2020). Um Panorama de Pesquisas do Campo da Educação Sobre a Lua e suas Fases. Ciência \& Educação (Bauru) [online]. 2020, v. 26 e20007. Epub 18 Maio 2020. ISSN 1980-850X. https://doi.org/10.1590/1516731320200007.

Gonzaga, E. P. (2009). Análise da evolução das concepções astronômicas apresentadas por professores de algumas escolas estaduais (Mauá, Ribeirão Pires e Rio Grande da Serra). (Dissertação de Mestrado, Universidade Cruzeiro do Sul, São Paulo).

Jafelice, L. C. (2002). Nós e os Céus: um enfoque antropológico para o ensino de Astronomia. Atas do Encontro de Pesquisa em Ensino de Física, Águas de Lindóia, 2128.

Jafelice, L. C. (2010). Abordagem Antropológica: educação ambiental e astronômica desde uma perspectiva intercultural. In: L. C. Jafelice (Org.), Astronomia, educação e cultura (pp. 213-299). Natal: EDUFRN.

Jafelice, L. C. (2015) Astronomia Cultural nos ensinos Fundamental e Médio. Revista Latino-Americana de Educação em Astronomia - RELEA, 19, 57-92. https://doi.org/10.37156/RELEA/2015.19.057.

Kriner, A. (2004). Las fases de la Luna: Cómo y cúando enseñarlas? Ciência \& Educação, 10(1), 111-120. Doi: http://dx.doi.org/10.1590/S1516-73132004000100008.

Lago, L. G. (2013). Lua: Fases e facetas de um conceito: uma discussão do ensinoaprendizagem a partir da Teoria da Atividade. (Dissertação de Mestrado, Universidade de São Paulo, São Paulo).

Lago, L., Ortega, J. L., \& Mattos, C. (2018). A Lua na mão: Mediação e Conceitos complexos no ensino de Astronomia. Ensaio Pesquisa em Educação em Ciências, 20. https://doi.org/10.1590/1983-211720182001020.

Lanciano, N. (1986). Weeks of Astronomy in the countryside. ESA Spec. Publ., ESASPE- 253, 211-215.

Lanciano, N. (1989) Ver y hablar como Tolomeu y pensar como Copérnico. Enseñanza de las Ciencias, 7(2), 173-182.

Langhi, R., \& Nardi, R. (2012). Educação em Astronomia: Repensando a formação de professores. São Paulo: Escrituras.

Laville, C., \& Dionne, J. (1999). A construção do saber: manual de metodologia da pesquisa em Ciências Humanas. Porto Alegre: Artes Médicas Sul.

Leite, C. (2002). Os professores de Ciências e suas formas de pensar a Astronomia. (Dissertação de Mestrado, Instituto de Física, Faculdade de Educação, Universidade de São Paulo, São Paulo). 
Leite, C. (2006). Formação do professor de Ciências em Astronomia: uma proposta com enfoque na espacialidade. (Tese de Doutorado, Faculdade de Educação,Universidade de São Paulo, São Paulo).

Lima, M. L. de S. (2006). Saberes de Astronomia no $1^{\circ}$ e $2^{\circ}$ ano do ensino fundamental numa perspectiva de letramento e inclusão. (Dissertação de Mestrado, Centro de Ciências Exatas e da Terra, Universidade Federal do Rio Grande do Norte, Natal).

Lorenzoni, F. (1988). Apprendre a regarder le ciel em dessinant. Une expérience d'Astronomie à l'Ecole élémentaire. Actes dixièmes Journées international essur l' Éducation scientifique, 259-265.

Oliveira, M. K. Pensar a Educação: Contribuições de Vygotsky. In: J. A. Castorina, E. Ferreiro, D. Lerner \& M. K de Oliveira (Org.). Piaget-Vygotsky: Novas contribuições para o debate. São Paulo: Ática.

Ministério da Educação (2017). Base Nacional Comum Curricular. Brasília, DF: Secretaria da Educação Básica.

Megid Neto, J. (2011). Gêneros de trabalho científico e tipos de pesquisa. In: M. U. Kleinke \& J. Megid Neto (Org.). Fundamentos de Matemática, Ciências e informática para os anos iniciais do Ensino Fundamental - Livro III (pp. 125-132). Campinas: FE/UNICAMP.

Pellenz, D. (2015). Astronomia no ensino de Ciências: uma proposta potencialmente significativa. (Dissertação de Mestrado, Universidade de Caxias do Sul, Caxias do Sul).

Penã, B. M., \& Quilez, M. J. G. (2001). The importance of images in astronomy education. International Journal of Science Education, 23(11), 1125-1135. https://doi.org/10.1080/09500690110038611.

Plummer, J. D. (2008). Early Elementary Students' Development of Astronomy Concepts in the Planetarium. Jornal of Research In Science Teaching, 46, 192-209. https://doi.org/10.1002/tea.20280.

Puzzo, D. (2005). Um estudo das concepções alternativas presentes em professores de Ciências de $5^{a}$ série do ensino fundamental sobre fases da Lua e eclipses. (Dissertação de Mestrado, Universidade Estadual de Londrina, Londrina).

Sarmento, M. J. (2011). Conhecer a infância: os desenhos das crianças como produções simbólicas. In: A. J. Martins Filho \& P. D. Prado (Org.). Das pesquisas com crianças à complexidade da infância (pp. 27-60). Campinas: Autores Associados.

Seniciato, T., \& Cavassan, O. (2009). O ensino de ecologia e a experiência estética no ambiente natural: considerações preliminares. Ciência \& Educação, 15(2), 393-412. https://doi.org/10.1590/S1516-73132009000200010.

Simon, P. C. S. G. (2016). Ensino de astronomia para os anos iniciais: uma proposta a partir da observação da lua. (Dissertação de Mestrado, Universidade Federal de São Carlos, São Carlos). 
Stahly, L. L., Krockover, G. H., \& Shepardson, D. P. (1999). Third grade students' ideas about the Lunar Phases. Journal of Research in Science Teaching, 36(2), 159-177. https://doi.org/10.1002/(SICI)1098-2736(199902)36:2<159::AID-TEA4>3.0.CO;2-Y.

Subramaniam, K., \& Padalkar, S. (2009). Visualisation and reasoning in explaining the phases of the Moon. International Journal of Science Education, 31(3), 395-417. https://doi.org/10.1080/09500690802595805

\section{Paula Cristina da Silva Gonçalves}

Doutoranda em Ensino de Ciências e Matemática pelo Programa Multiunidades em Ensino de Ciências e Matemática - Unicamp. Coordenadora Pedagógica da Rede Municipal de Rio Claro -,SP. Integrante do Grupo de Pesquisa FORMAR- Ciências da Unicamp. Rio Claro, SP, Brasil. E-mail: paulacristinasgoncalves@gmail.com

\section{Paulo Sergio Bretones}

Doutor em Ensino e História de Ciências da Terra pela Unicamp. Professor Associado do Departamento de Metodologia de Ensino e do Programa de Pós-Graduação Profissional em Educação da UFSCar, São Carlos, SP, Brasil.

E-mail: bretones@ufscar.br

Contato:

Secretaria Municipal de Educação Rua Dr. Eloy Chaves, n $^{\circ} 3265$ - Alto Santana

Rio Claro, SP - Brasil

CEP 13504-188

Editor Responsável

Glauco Santos Ferreira da Silva

Centro de Ensino de Ciências e Matemática de Minas Gerais - CECIMIG Faculdade de Educação - Universidade Federal de Minas Gerais revistaepec@gmail.com 